\title{
COVID-19: Impact and Opportunities in Gabon
}

\author{
Stephan Yannick Popouet \\ School of Politics and International Studies, Central China Normal University, Wuhan, China \\ Email: stephanyannickpopouet@gmail.com
}

How to cite this paper: Popouet, S. Y. (2021). COVID-19: Impact and Opportunities in Gabon. Open Journal of Social Sciences, 9, 167-185.

https://doi.org/10.4236/jss.2021.98012

Received: July 1, 2021

Accepted: August 7, 2021

Published: August 10, 2021

Copyright $\odot 2021$ by author(s) and Scientific Research Publishing Inc. This work is licensed under the Creative Commons Attribution-NonCommercial International License (CC BY-NC 4.0). http://creativecommons.org/licenses/by-nc/4.0/ (c) (i) (8) Open Access

\begin{abstract}
Since the discovery of Coronavirus (COVID-19) in December 2019, the World has been facing a new strain of virus that has not been previously identified in humans and has rapidly been affecting people around the World. Initially less affected, the African continent reported more than 4,360,383 cases in general with more than 20,636 confirmed cases in Gabon. This research will present the impact of the COVID-19 pandemic in Africa in general with a particular view of the case of Gabon. This perspective aims to update data and provide information on the pandemic situation for the small central African country. This research will first explore the economic impact of the global pandemic on a developing country like Gabon, Gabon's strategies in combatting the virus and the opportunities presented by COVID-19. Documentary and qualitative research methods were used to analyse this topic.
\end{abstract}

\section{Keywords}

COVID-19, Impact, Africa, Gabon, Responses, Economy, Opportunity

\section{Background}

The first human cases of COVID-19, the disease caused by the novel coronavirus subsequently named SARS-CoV-2 was first reported by officials in Wuhan City, China, in December 2019. Retrospective investigations by Chinese authorities have identified human cases with onset symptoms in early December 2019. While some of the earliest known cases had a link to a wholesale food market in $\mathrm{Wu}$ han, some did not. Many of the initial patients were either stall owners, market employees, or regular visitors to this market. Environmental samples taken from this market in December 2019 tested positive for SARS-CoV-2, further suggesting that the market in Wuhan City was the source of this outbreak or played a role in the initial amplification of the outbreak. The market was closed on 1 January 2020 (WHO, 2020). In the World Health Organization's regular update 
on 13 April 2021, globally, new COVID-19 cases rose for a seventh consecutive week, with over 4.5 million new cases reported in the previous week. The number of new deaths increased for the fourth consecutive week, increasing by $7 \%$ compared to the week before, with over 76,000 new deaths reported (WHO, 2021). Table 1 presents the confirmed and death cases of COVID-19 according to various regions.

Several early publications from the Wuhan region of China focused on describing clinical characteristics of hospitalized patients with severe COVID-19 illness. These initial observational studies demonstrate in severe cases evidence of coagulation dysfunction through elevated D-dimer, elevated lactate dehydrogenase, elevated total bilirubin, and decreased platelets with slight or no changes in partial thromboplastin time or activated partial thromboplastin time (Campbell, 2020). Amidst the significant public health risk COVID-19 poses to the world, the World Health Organization (WHO) first declared a public health emergency of international concern to coordinate international responses to the disease (McKibbin \& Fernando, 2020). After the disease caused by the new coronavirus started spreading to more than 100 countries, leading to tens of thousands of cases within a few months, the World Health Organization officially declared the outbreak of COVID-19 a pandemic (Rettner, 2020). The World Health Organization has been cautious in its decision to declare a pandemic because the word, "If misused, can cause unreasonable fear, or unjustified acceptance that fight is over" Ghebreyesus, the director-general of WHO said. From the beginning of the spread, countries such as the United States, Brazil, India, Spain or Italy have been most affected. Table 2 is a presentation of the ten most affected countries around the world. While the world is struggling to control COVID-19, the People's Republic of China has managed to control the pandemic rapidly and effectively (Burki, 2020). The novel coronavirus disease was declared a public health crisis, a virus that has been originally contained to China's borders has now broken out in several corner of the World (Horowitz, 2020).

Table 1. COVID-19 confirmed cases and deaths by region.

\begin{tabular}{ccc}
\hline Region & Confirmed cases & Deaths \\
\hline Europe & $48,928,105$ & $1,113,821$ \\
North America & $41,007,690$ & 924,724 \\
Asia & $57,699,627$ & 822,399 \\
South America & $34,012,610$ & $1,036,720$ \\
Africa & $6,001,373$ & 152,198 \\
Oceania & 82,341 & 1326 \\
\hline
\end{tabular}

Source: Reported Cases and Deaths by Country or Territory (by WORLDOMETER, 2021a) Last update: July 12, 2021, 10:40 GMT available at:

https://www.worldometers.info/coronavirus/?utm campaign=homeAdvegas1? 
Table 2. The ten most affected countries around the world.

\begin{tabular}{ccc}
\hline Country & Confirmed cases & Deaths \\
\hline USA & $34,732,753$ & 622,845 \\
India & $30,889,453$ & 409,130 \\
Brazil & $19,089,940$ & 533,546 \\
France & $5,812,639$ & 111,325 \\
Russia & $5,808,473$ & 143,712 \\
Turkey & $5,481,555$ & 50,229 \\
UK & $5,121,245$ & 128,425 \\
Argentina & $4,647,948$ & 98,781 \\
Colombia & $4,511,960$ & 112,826 \\
Italia & $4,271,276$ & 127,775 \\
\hline
\end{tabular}

Source: Reported Cases and Deaths by Country or Territory (by WORLDOMETER, 2021b) Last update: July 12, 2021, 14:41 GMT available at:

https://www.worldometers.info/coronavirus/?utm campaign=homeAdvegas 1 ? $\% 22 \% 20 \% 5 \mathrm{Cl} \% 20 \% 22$ count ries $\% 3 \mathrm{Ca} \% 20 \mathrm{href}=$

In a strongly connected and integrated world, the impacts of the disease have become apparent since the outbreak. This impact has gone beyond deaths rather greatly impacted people's ability to work for a period of time. Amid the slowing down of Chinese economy with interruptions to production, the functioning of global supply chains has been disrupted. Many companies in different sectors around the world, irrespective of size, that is dependent upon inputs from China have started experiencing changes in production. Limitation on transport and restrictions among countries has further slowed global economic activities down. Most importantly, some panic among consumers and firms have distorted usual consumption patterns and created market anomalies. Global financial markets have also been responsive to the changes and global stock indices have plunged (McKibbin \& Fernando, 2020). The biggest impacts on GDP occur when people reduce their social consumption in an effort to protect themselves from the disease. However, falls in social consumption does not scale up all scenarios by the same amount, for the simple reason that supply and demand are complimentary. If school closures and people taking more time off work increase the size of the supply shock, the demand shock has less scope to do damage (Wren-Lewis, 2020).

When COVID-19 initially blazed through Asia, Europe and then the United States, global public health experts worried that it could be catastrophic for Africa, with its crowded cities, poorly funded health sector and lack of testing facilities. The U.N. Economic Commission for Africa in April predicted up to 300,000 deaths in the 2020 if the virus couldn't be contained on the continent (Beker, 2020). Despite the emergence of the new coronavirus variations in Africa which has led the number of both new cases and deaths to increase in many countries the continent remains the least affected. Table 3 shows the top 10 
Table 3. Top 10 affected countries in Africa.

\begin{tabular}{ccc}
\hline Country & Confirmed cases & Deaths \\
\hline South Africa & $2,005,065$ & 152,246 \\
Morocco & 542,462 & 9,369 \\
Tunisia & 497,613 & 16,388 \\
Egypt & 283,102 & 16,396 \\
Ethiopia & 277,071 & 4343 \\
Libya & 206,769 & 3243 \\
Kenya & 188,754 & 3243 \\
Zambia & 176,742 & 2867 \\
Nigeria & 168,552 & 2124 \\
Algeria & 146,064 & 3836 \\
\hline
\end{tabular}

Source: Reported Cases and Deaths by Country or Territory (by WORLDOMETER, 2021b) Last update: July 12, 2021, 15:02 GMT available at:

https://www.worldometers.info/coronavirus/?utm campaign=homeAdvegas1?\%22\%20\%5Cl\%20\%22count ries\%3Ca\%20href=

affected countries in Africa after the second wave of COVID-19.

As of April 14, 2021, the number of confirmed COVID-19 cases in Africa amounted to 4,421,267 which represented around 3.18 percent of the infections around the world. By the same date, coronavirus cases globally were over 138.8 million, causing nearly 2.98 million deaths, while approximately 111.6 million people recovered from the disease. In the African continent, South Africa was the most drastically affected country, with more than 1.56 million infections. (Galal, 2021).

Gabon is ranked $26^{\text {th }}$ most affected country in Africa with 21,566 confirmed cases and 132 deaths (Galal, 2021). The African continent first came in contact with the coronavirus pandemic on February 14, 2020, in the northernmost part, particularly Egypt. Since then, the government of different countries like Gabon took severe restrictive measures to try to curb the spread of the disease. Moreover, the official numbers of the African continent are significantly lower than those of Europe, North America, South America, and Asia. Nevertheless, the infectious disease still managed to have its effects on several countries (Galal, 2021).

This paper would examine the effects of COVID-19 on both Africa and the Gabon region, the strategic response adopted by Gabonese authorities, the impacts of the virus on Gabon's economy, opportunities presented and some solutions to help the country fight this pandemic.

\section{The Impact of COVID-19 in Africa}

There is not any form of homogenous native around the COVID-19 pandemic in Africa, as in other countries. The pandemic affects each nation differently, despite varying strengths and weaknesses. As a result of the rapid spread the novel coronavirus which first appeared in Egypt on 14 February 2020 spread two 
months later to other areas of the continent. African countries started closing their borders and other countries introduced robust strategies with contact tracing to map transmission and isolating suspected individuals from infection (WHO, 2020). While the spread of COVID-19 across sub-Saharan Africa has been more modest than once feared, the strict lockdown measures and the global economic shock have disrupted livelihoods and stalled efforts against other health scourges in the region such as HIV and TB (Stanford University, 2020).

\subsection{Impact on the Economy}

Against the backdrop of this worrying public-health situation, African countries are facing the impact of the global pandemic on African economies. This includes disruption in global supply chains exposed to inputs from Asia, Europe, and the Middle East, as well as lower demand in global markets for a wide range of African exports. Moreover, Africa is likely to experience delay or reduced Foreign Direct Investment (FDI) as partners from other continents redirect capital locally. Secondly, the economic impact of the spread of the virus within Africa, and of the measures that governments are taking to stem the pandemic. Travel bans and lockdowns are not only limiting the movement of people across borders and within countries, but also disrupting ways of working for many individuals, businesses, and government agencies. Thirdly, the collapse of the oil price, driven by geopolitics as well as reduced demand in light of the pandemic. In the month of March 2020, oil prices fell by approximately 50 percent. For net oil-exporting countries, this has resulted in increasing liquidity issues, lost tax revenues, and currency pressure (Jayaram, Leke, Ooko-Ombaka, \& Sun, 2020).

Due to COVID-19 lockdowns, South Africa's Gross Domestic Product (GDP) fell $51 \%$ from the first to second quarters of 2020. A recent World Bank report suggests that 26 million to 40 million more sub-Saharan Africans could fall into poverty as a result of the pandemic. At the same time, some African economies are showing early signs of economic recovery. As of June 2020, almost all of the 54 African countries had suspended their international flights, 38 countries had announced the closure of their land borders and 17 countries had closed their maritime borders. Since mid-September, international commercial flights to Kenya, Rwanda, Ghana and Nigeria have resumed, but not flights to South Africa (GIGA Focus Afrika, 2020). It is also important to know that many African countries are resource-dependent. They rely on revenues generated from the export of oil. Five out of the top 30 oil-producing countries in the world are in Africa: Nigeria, Angola, Algeria, Libya, and Egypt. Other important oil-producing countries include Sudan, Republic of Congo, Equatorial Guinea, and Ghana. In 2019, the continent accounted for more than 7.9 million barrels of exports per day, which is 9.6 percent of the world's output (Carpenter, 2020).

Many African countries rely on external funding to complete their annual budget spending, countries like Ethiopia may see a decline in external funding during the COVID-19 pandemic period. The most affected countries would be 
countries that rely on substantial foreign funding, as health spending is extremely high and the most important priority (Avila et al., 2013). African countries face much greater problem of the management of not only COVID-19 but also of ensuring that the bulk of its resources are not channeled to COVID-19 leaving malaria, HIV/AIDS, and TB, among others, with an enormous gap in the global economy. Therefore, it would be a big challenge in West Africa to sustain a sufficient health budget to resolve all existing health issues, and not only COVID-19 (Schneider et al., 2020).

\subsection{Impact on Food Security and Household Income}

A new survey from four African countries on the COVID-19 pandemic shows significant impacts on food security and household income, and that COVID-19 has women apprehensive about accessing health care. Food security has been severe and pervasive since the start of COVID-19 restrictions. According to the survey, 30\% of women in Kenya report that at least one member of their household went without food since COVID-19 restrictions were imposed, with 72\% reporting that food insecurity is more common now compared to before restrictions began. Between $20 \%$ and $50 \%$ of women in the countries surveyed needed to visit a health facility during COVID-19 mobility restrictions, but over $20 \%$ of them reported fear of the virus at the health facility (Wells, 2020). The onset of the COVID-19 crisis has exponentially increased the continent's food security problems. Food supply chain distribution networks have been severely constrained. The numerous negative impacts of the health crisis are having a compound effect on all facets of food security, including food production, safety and distribution. Regional lockdowns, curfews, closures of markets, restrictions on border crossings and movement limitation measures (while necessary for public health and safety concerns), hamper the functioning of the agricultural sector, and Small to Medium Enterprise (SMEs) that make up the continent's supply chain backbone. These restrictions exacerbate food insecurity and nutritional deficits issues across Africa, affecting: Agriculture; Manufacturing and Distribution (AERC Africa, 2021). Global food prices rose close to $20 \%$ in the 2020 , consistent with broad movements of other commodity prices and U.S. currency trends. The primary risks to food security are at the country level: Higher retail prices, combined with reduced incomes, mean more and more households are having to cut down on the quantity and quality of their food consumption (The World Bank, 2021). The COVID-19 pandemic has crippled a number of African agricultural exports, while dependency on food imports and lower purchasing power across much of the continent threaten to push millions more into food insecurity and poverty (Kurtz, 2020).

\subsection{Impact on Budgetary Balance and Debts Burdens}

According to a report published by the African Development Bank, in 2020, government spending across Africa skyrocketed as countries strived to support 
their populations through the pandemic. This has had a direct negative impact on budgetary balances and debt burdens: the average debt-to-GDP ratio for Africa is expected to climb by 10 to 15 percentage points in the short to medium term, fueled by the surge in government spending and the contraction of fiscal revenues as a result of COVID-19. This will result in fast-paced debt accumulation in the near to medium term. Although the average debt to-GDP ratio had stabilized around 60 percent of GDP, recent debt restructuring experiences in Africa have been costly and lengthy because information asymmetries, creditor coordination problems, and the use of more complicated debt instruments, the report said (African Development Bank Group, 2021).

\subsection{Impact on Unemployment Rate}

According to Hoyt 2020, the collapse of the global economic recession is having a major impact on countries in sub-Saharan Africa. Indigenous businesses, which are mostly small businesses, will have to lay off their workers due to lockdowns, and people will be left without pay, which will further increase poverty. Due to the slower growth rate of developed economies, African countries will go through a difficult period. The African continent faces a simultaneous health and economic crisis that threatens to cripple health systems, damage livelihoods and weaken the region's development prospects for years to come. Africa already has its fair share of challenges, such as slower growth and overall poverty reduction, at different rates in different African countries. Africa's COVID-19 crisis could undo years of development progress (OECD, 2020).

\section{Gabon Facing COVID-19 Pandemic}

Gabon, like other countries around the world, has initiated a form of restriction in order to slow the spread of the virus on its territory. After the appearance of the first case on March 12, 2020 and the 55 cases officially declared on April 12, Gabon is still considered to be a country spared by the virus which continues to gain ground in other countries in the continent. This did not prevent the authorities from quickly putting in place preventive measures such as the state of health emergency declared by the President on April 9.

Some mathematical models, such as that of Imperial College London, suggests the possibility of 2,051,004 cases of infection out of a total population of $2,225,728$ inhabitants, or $92 \%, 39,934$ cases of hospitalization and 5726 deaths from the virus. If it is still difficult to predict the future, this extreme scenario seems unlikely. However, according to the current evolution of the epidemic, the measures taken very early by the authorities and the age pyramid in Gabon as well as the rest of Africa. Indeed, more than $60 \%$ of the inhabitants are under 25 years old, against $17 \%$ in Europe, and the number of cases of obesity is relatively low. In addition, the average level of Gabon's health infrastructure is relatively high, compared to the rest of Africa. In the 2019 ranking of the United Nations Development Program (UNDP), which considers aspects of health-but also 
education, etc.-Gabon certainly ranks 115th in the world, but ranks 3rd in mainland sub-Saharan Africa (Michael, 2020).

Initially, the measures taken by the Gabonese authorities included the prohibition of access to the national territory for nationals of high-risk countries and strengthen the national response system against a possible Coronavirus epidemic at the borders, which then evolved into strict social distancing measures (closure of schools, closure of restaurants, ban on gatherings of 30 or more people, closure of all places of worship, cancellation of all hearings). A national steering committee has been set up under the supervision of the Prime Minister, as well as a national response committee coordinated by the Ministry of Health and Military Medical Services. In order to strengthen the response, the country has set up a scientific committee whose role is to provide scientific and technical support to the Steering committee (The World Bank, 2020).

In general, Gabonese strategy can be summed up in two words: reactivity and progressiveness. The authorities sought to intervene very early, as early as possible, by multiplying preventive measures, which they gradually tightened as the threat increased: screening at the airport with taking of temperature by thermoflash, quarantine, closure of land borders as soon as the first cases appeared in neighboring countries, followed by air and sea (excluding goods), closure of establishments open to the public and partial curfew (from 8 p.m. to 6 am). This was announced and implemented from April 10 until the total confirmed of greater Libreville which is Gabon's capital and its neighboring municipalities because majority of cases (around 95\%) are concentrated within these areas. Such a measure therefore made it possible to limit the risks of the virus spreading to other provinces. The general idea is to prevent rather than cure considering the level of health infrastructure which is much lower than in the countries of the North (Michael, 2020).

While the country has been living in a state of health emergency since April 9, 2020, the impact of containment measures is weighing more and more on the economy (Schiex, Nze, \& Niamkey, 2020). To revive this economy, the minister in charge of the economy and its recovery with his colleagues concerned by the economic recovery plan, defined during a meeting on December 3, 2020 the exes of the recovery strategy of the post-COVID-19 economy. This strategy will be based on seven sectors identified as growth promoters, including mining, hydrocarbons, agriculture, fishing, trade, tourism and energy. The question of financing was also raised during this Cabinet Council. For the Minister in charge of Recovery, the Gabonese state must rely on its own resources. All that was planned should be carried out from 2021 until 2023, in order to revitalize economic activity and improve the daily lives of populations (Brice, 2020).

At the same time, public finance reforms occupy a prominent place. Therefore, focusing on six main points such as:

- Optimization of oil revenues; 
- Reform of property taxation;

- Formalization of the informal sector;

- Taxation of electronic money transactions;

- Rationalization of expenses;

- Progressive constitution of national savings (Eyene, 2020a).

With the same objective of relaunching the economy, due to their proximity to Small and Medium Enterprises, microfinances could play a major role.

A control visit to micro financial institution on November 10, 2020 aimed to gain insight into the evolution of banking services and the digitization of customer services for these secondary level financial structures. According to the member of the government, it was also a question of seeing to what extent, this sector could play as a major role in the revival of the economy. As a reminder, the national microfinance landscape is made up of 19 establishments (6 savings and credit cooperatives, and 13 public limited companies). It is dominated by four main structures (Finam, Loxia, EDG and Express-Union) which alone bring together nearly $95 \%$ of the sector's customers. In the first half of 2020, deposits collected from the sector amounted to FCFA 60.1 billion, against FCFA 37.2 billion in the same period in 2019. As for customer loans, they amounted to 51.7 billion FCFA during the first six months of the year, against 32.46 billion FCFA, in the first half of 2019 , an increase of 59.3\%. A performance dependent on raising the banking rate as well as efforts to support the operating needs of Small and Medium Enterprises (Eyene, 2020b).

\section{Socio-Economic Impact of COVID-19 in Gabon}

The COVID-19 pandemic has impacted the economy of Gabon's supply economy with industries, hotels, shops and offices closed due to the lockdown that has seriously affected salaries of different workers that is regular, weekly, and monthly workers of both traditional and modern household workers who are currently unable to participate in any profitable trade as markets are partially closed in line with public transport restrictions. Figure 1 is a presentation of confirmed cases in Gabon according to different regions of the country. Citizens have been locked in their homes with no customers, no visitors, no shoppers, and no passengers on the demand side of the economy, thereby dramatically affecting the regular, weekly, and monthly household profits.

The COVID-19 pandemic has not had a strong health impact in Gabon, with only 158 officially registered deaths in a country of 2 million citizens. This, unlike the rest of the world where COVID-19 is at the origin of $0.3 \%$ of usual mortality, undoubtedly is due to the young population rate (only $4 \%$ is over 65 years old) and immunity by exposure to other pathogens (Bourdillon, 2020). On the other hand, the economic impact has been considerable because COVID-19 pandemic struck Gabon when the country had succeeded in restoring its macroeconomic framework at the end of 2019. In fact, the country started in 2010 a process of economic diversification via the Strategic Plan Emerging Gabon which the 


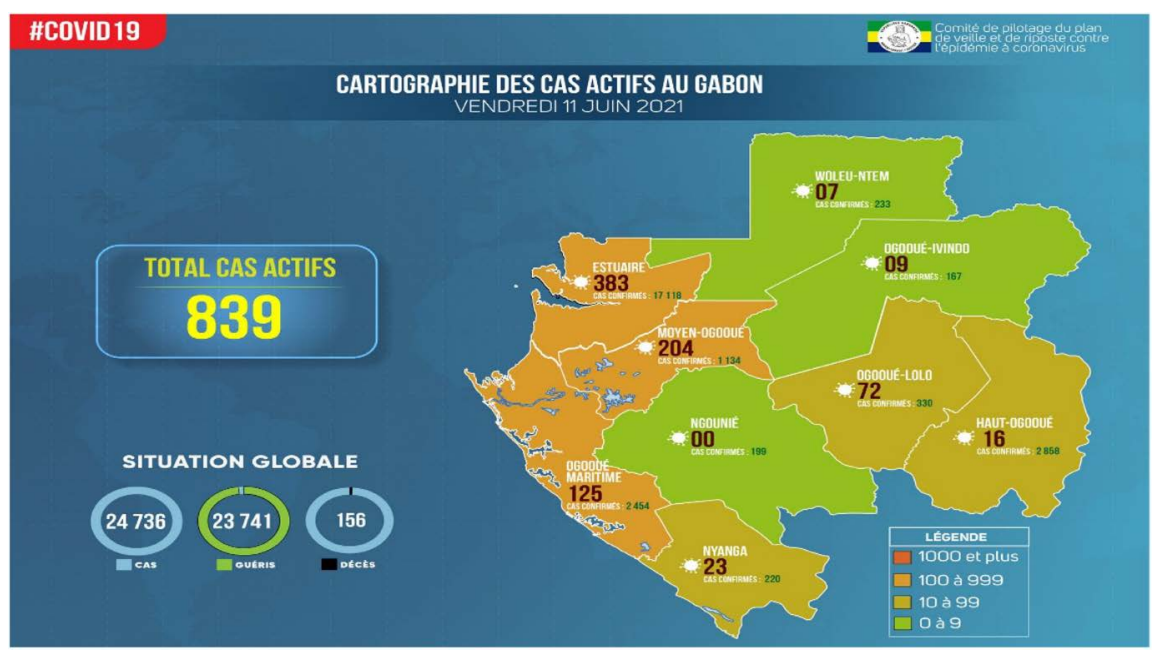

Figure 1. Mapping of active cases in Gabon, 2021. Source: Infor COVID-19 GABON. Data sourced from

https://twitter.com/Covid19GOUVGA/status/1403458258170519553 data reports as of June 11, 2021 (Info Covid19 GABON, 2021).

implementation was slow due to the fall in prices of oil by $50 \%$ in 2014 . The efforts made between 2017 and 2018 allowed the economy to rebound; after almost zero growth in 2017 and 2018, it reached 3.3\% in 2019. This progress called into question by COVID-19 if strong measures are not taken to accompany the end of this pandemic (UNDP, 2020).

According to the IMF, the pandemic has worsened situation that was already marked by the difficult economic situation in the raw materials market. In the first quarter of 2020 , oil production increased by $5.3 \%$ compared to the same period of 2019, but exports fell by around $20 \%$ due to the drop in prices and global demand. Likewise, exports of timber fell by $11 \%$ and the turnover of the wood industry manganese fell by $12.5 \%$. In addition to the mining sector, this crisis is spreading over the national economy, in particular within the service sectors (hotels, land and air transport, and other services). This decline in domestic non-oil activity is exerting significant pressure on public finances and public debt. Thus, non-oil tax revenues fell by $11 \%$ in April 2020, and VAT has fallen about $16 \%$. In its last report presenting the disbursement of the second tranche of US\$150 million in budget support to Gabon, the IMF took note of Gabon's commitment to lower $23 \%$ of its oil production in 2020 following the OPEC agreement. The IMF also assumed a weakening of the global demand for manganese and timber. It also expects a more difficult situation for non-oil activity, in particular services, following containment measures (UN, 2020).

The heath crisis linked to the COVID-19 pandemic has greatly affected the Gabonese economy with more than 12,000 jobs lost in 2020. The oil sector which represents more than $80 \%$ of the country's income is severely affected resulting in the fall in the growth rate, which fell from almost 5\% in 2019 to $1.5 \%$ (FinDev, 2021). Companies are not immuned to the harmful effects of COVID-19 pandemic and those within manufacturing sector which requires a contribution 
of imported inputs risk to be in a situation of decline in production, performance and revenue. Before COVID-19, in 2019, only 8.5 percent of companies had turned to banks for the financing of their start-up activities. After the health crisis, these SMEs (Small and Medium Enterprises) would risk to be in an even more unfavorable disposition as the commercial banks themselves would have difficulty carrying out their operations banking due to a probable contraction in deposits of liquidity by economic agents. The consequences are also seen in employment and Gabon's labor market. The impact on employment is greater in urban areas than in rural areas, particularly in Libreville and PortGentil. Thus, $15.3 \%$ of households have at least one member who lost a job due to coronavirus. This proportion is $20.7 \%$ in Port-Gentil, $16.7 \%$ in Libreville and Franceville, $13.8 \%$ in other cities and 11.8 percent in rural areas. The consequences in terms of job losses were more obvious in the formal sector than in the informal sector, mainly because the formal sector has been more inclined to strict compliance with preventive measures enacted by the government (Ministry of Economy and Finance, 2020). In the same perspective, a study of the general direction of statistics goes further by investigating the impact of covid19 on the living conditions of households in Gabon in 2020. From this study the following figures emerge: nearly six out of ten households say they have been affected. The most mentioned being the loss of employment cited by $53.6 \%$ of households; the increase in the price of major staple foods, cited by nearly one in four households (23.5\%), and business bankruptcy, which is expressed by one in ten households (11.5\%) (Eyene, 2020c).

\section{Opportunities Presented by COVID-19 for Gabon}

COVID-19 has a lot of dark side. Around the world, people have gotten sick and died, schools have closed, healthcare system overloaded, employees lost their jobs, companies face bankruptcy, stock markets collapsed and countries have to spend billions on bailouts and medical aid. The effect of COVID-19 on everyone has been intensive whether directly affected or not. COVID-19 has been a huge stressor shaking up our psyche, triggering our fears and uncertainties. No matter how serious and sad the situation is, there are benefits too.

\subsection{The Importance of e-Commerce}

The Covid19 pandemic has highlighted a number of challenges for global economy and commerce around the world. For the first time, digital technologies offered an alternative channel to maintain business activities and social interactions during times of strict containment. Covid19 has demonstrated the special role that e-commerce can play during the crisis and beyond. While the Covid19 crisis has boosted the dynamism of e-commerce, it has also exposed pre-existing challenges facing aspiring e-commerce entrepreneurs around the world. These include regulatory differences such as access to online payment solutions, reliable internet and power connections, prohibitive costs of trading across borders, 
visibility in online searches and advertising and, sales platforms. The pandemic has also underscored the critical importance of bridging the digital divide both within and between countries. In addition, Covid19 has highlighted the need to answer questions about the extent to which small producers, sellers and consumers in developing countries and economies in transition can benefit from the opportunities offered by e-commerce (UNECE, 2021).

\subsection{Speed and Innovation}

Many bureaucratic organizations with slow procedures, rigid hierarchies that have managed organizational have been forced by COVID-19 to break through these rigid systems and act instantly. As a result, procedures were skipped or changed and decisions were made more autonomously without formal approval. Suddenly, employees are allowed to work from home without direct supervision. The Covid19 shows that, as soon as there is a strong enough stimulus, things can change. This leads to remarkable innovations. Not being allowed to open their doors, restaurants, for example, switch to delivery mode. And schools suddenly do a lot of the teaching and even some of the exams online. This offers the opportunity to create innovations now that can be sustained after the crisis. And it can also help keep the current speed and innovation mode afterwards (Kraaijenbring, 2020).

\subsection{Opportunity on the Reinitialization of the Educational System}

The pandemic has deepened inequalities and heightened the urgency to fill the gaps for the most marginalized learners. Radical inclusion should be the next normal. The vast majority (84\%) come from middle- and low-income countries, where distance education technologies do not reach all children and reinforce and accelerate inequalities, especially for girls, preschool children and children with special needs. Radical inclusion policies for distance and in-person learning must emerge (Randa, 2020).

\subsection{A Boost in Local Products and Services Production}

Reduction in intermediate goods imported in Gabon could significantly slow production activities. However, cuts in imports of goods and services are expected to reduce the demand on the country. This has a positive effect on the level of currencies and the net international reserves. It also offers import substitution opportunities, thus stimulating the production of local products and services. Due to lack of industrial production, initiatives are flourishing across the continent to produce alternative "masks in large quantities". The campaign for the wearing of the compulsory mask is now underway across Africa. Especially since some countries are starting to relax the containment measure imposed on populations. In Gabon, where the authorities have decided to relax containment measures in the capital Libreville, wearing a mask has been compulsory since April 15. Here too, the alternative fabric mask is in order. Many 
local workshops produce loincloth masks that are sold like hot cakes (Mateso, 2020).

\subsection{Health Care Delivery}

The pandemic has pushed Gabon to strengthen its health system by obtaining equipment to fight against the virus. The Ministry of Health received on November 11, 2020 in Libreville, a batch of equipment and supplies, such as ambulances, personal protective equipment and diagnostic kits for laboratory screening. This material is part of a loan of 5 billion CFA francs contracted with the World Bank via the International Bank for Reconstruction and Development. This project aims to strengthen the country's health system, particularly in the prevention, detect ion and management of cases, in accordance with Gabon's COVID-19 preparedness and response plan. It will also finance the training of health personnel and the establishment of two new diagnostic centers for COVID19 (Mounombou, 2020).

\subsection{COVID-19 Lockdown Boosts Golds Sales in Gabon}

Travel restrictions had the unexpected effect of redirecting artisanal gold flows to the Gabonese government's legal purchasing agency, $\mathrm{CGCO}^{1}$ (Comptoir Gabonais de Collecte de l'Or). According to a source within the CGCO, the government counter bought around $100 \mathrm{~kg}$ of artisanal gold over a two-month period from mid-March to mid-May 2020. The CGCO bought only $42.8 \mathrm{~kg}$ for the whole of 2013 and only $28.9 \mathrm{~kg}$ for the whole of 2014 . The rate of purchase of the CGCO during the COVID-19 pandemic is thus between 10 and 20 times higher than before the pandemic. The closure of Gabon's land and air borders has left the CGCO as the only viable option for miners seeking to sell their gold production. Artisanal gold sales at CGCO, according to Moussounda, had already increased slightly in January and February before the COVID-19 exploded from March as travel restrictions closed the first gold hubs like Dubai then Gabon's own borders (Blore, 2020).

As it says in the Monty Python song "Always look on the bright side of life", let's not forget them and take the best part of what the crisis gives us. COVID-19 has shown the importance of certain things like E-commerce, it has also brought speed in the work for certain organisations and innovation in the work of many structures. Also, we have seen that COVID-19 has also helped to identify shortcomings in the educational system that will help improve the system if these points are considered. Local products and services were also showcased showing the importance of local businesses in a country's economy. It is also important to point out that COVID-19 helped to realize the deficiencies of the health system and increased the sale of gold by redirecting artisanal gold flows to the Gabonese government's legal purchasing agency due to border closures and travel restrictions.

${ }^{1}$ CGCO, Gabonese Gold Collection Counter. 


\section{Conclusion and Suggestions}

The pandemic has shown the ability of countries around the world to respond to an emergency situation. Despite the tragic deaths and the effects of undeniable economic suffering, COVID-19 has brought an unprecedented change in the world. The transformation and improvement of customer service, the Internet industry and other relevant sectors has accelerated. In a new round of growth opportunities, E-commerce, E-government, home office, virtual business, online education and other new types of businesses will be considered more. Regarding the case of Gabon, we can say that the country has withstood the first wave of impact but significant socio-economic challenges will continue to arise in the coming months. It is urgent to amortize the current shocks, to prepare for a future that is more resistant to viruses and take advantage of the crises to relaunch the green and digital transition of Gabon towards a sustainable economy.

Suggestions help fight the spread of COVID-19.

- A strong and scalable social protection

To reduce the spread of the virus, many African countries quickly implemented containment measures even when there were very few confirmed cases. However, containment and social distancing will be difficult to maintain, especially in countries without scalable social protection systems. The majority of workers across the continent operates in the informal sector and many survive on what they earn each day through direct transactions. Even to find water which is essential for preventing and daily life. Therefore, many people are forced to leave their homes. Without effective social distancing, testing and contact tracing becomes less useful, if not inapplicable. Rigorous implementation of the rules does not change this; rather, it risks fuelling a certain resentment that would make their respect less likely (Riku \& Alexander, 2020).

- A development of health system

All African governments should create an enabling environment for the evolution of competitive health systems through prioritization. Governments should work towards empowering wealth creation efforts, adopt a system approach that would understand the interdependence of African issues, and outline how to address the largely weak health issues as quickly as possible (Klomegah, 2020). Like other sectors such as education, the absence of a strategic vision of the public power to invest in essential sectors of governance is the main cause of failure. The result is a lack of strategic, technical and operational framework. Also, if it happens, due to pressure from development partners, that a strategic document be drawn there is no operational mechanism, no monitoring framework, or no evaluation. The logical consequence of these shortcomings is the quasi-structural weakness of health systems. Also, in Africa, COVID-19 reveals the need to involve citizens in health systems. The disinterest of some populations in the disease is related to distrust of political authorities. The COVID-19 has not yet caused as much loss of human life as in Western states, it is nevertheless necessary to build an inclusive strategic reflection on the basis of this pandemic. Like Ebola, which shook the fundamentals of the Guinean, Liberian and Sierra Leonean 
states, the COVID-19 pandemic may be the harbinger of other types of calamity. This episode should mobilize, within African States, structural approaches to community health free from corruption, by involving citizens in the management of their own health systems (Olagboye, 2020).

- Location of an African industry

Africa can take advantage of the post-crisis period, and in particular the tectonic movements it could unleash in China and Asia, to rethink its industry. First, by locating it on the continent and serving its own markets with its local production. Tires could be produced in countries where rubber trees grow and where there are developed automotive markets such as Cote d'Ivoire or Nigeria. The Congo Basin could become a stronghold in the production of furniture, like the factory in the Nkok complex in Gabon. Mango, passion fruit and pineapple juices from the Bamako and Dakar markets should stop being "made in Thailand" and come from national or sub-regional processing plants, like the Sobema juice factory in Mali (Benjamin \& Wilfried, 2020).

- Communication improvement and public awareness strategy

In the case of Gabon, it is important to avoid managing the health crisis under pressure from public opinion, as well as the depoliticization of this management. It is also important to improve the communication and public awareness strategy and prioritize the protection and motivation of personnel engaged in the fight against the COVID-19 pandemic. While shedding light on the problem of containment, its objectives and its merits in view of reluctance of the population. As for screening, an increase in the number of tests to be done per day would be desirable, as would increase in the number of laboratories for diagnosis. Effective management in the event of the development of the disease must be guaranteed (Dzonteu, 2020).

Section 3 and Section 4 are connected because both aim to explore COVID-19 situation in Gabon. The only difference is that in Section 3, it is all about how the country reacts to fight the virus or more specifically an analysis of the Government strategies adopted to fight the virus while Section 4 is dedicated to analyze the socio-economic impact of COVID-19 in Gabon.

\section{Limitation of the Study}

There is not enough previous research on this topic and because the COVID-19 pandemic is ongoing, the Gabonese government continue to update its protocols and control solutions periodically.

\section{Conflicts of Interest}

The author declares no conflicts of interest regarding the publication of this paper.

\section{References}

AERC Africa (2021). The Impact of COVID-19 on Food Security in Africa. https://aercafrica.org/latest-news/the-impact-of-covid-19-on-food-security-in-africa/ 
African Development Bank Group (2021). African Economic Outlook 2021: Africa's Growth Prospects Bullish Despite COVID-19 Constraints and Debt Burden.

https://www.afdb.org/en/news-and-events/press-releases/african-economic-outlook-20 21-africas-growth-prospects-bullish-despite-covid-19-constraints-and-debt-burden-42 692

Avila, C., Catherine, C., \& Peter, A. (2013). Universal Coverage of Essential Health Services in Sub-Saharan Africa: Projections of Domestic Resources.

https://www.hfgproject.org/universal-coverage-of-essential-health-services-in-sub-saha ran-africa-projections-of-domestic-resources-2/

Beker, A. (2020). Why Africa's COVID-19 Outbreak Hasn't Been as Bad as Everyone Feared. TIME. https://time.com/5919241/africa-covid-19-outbreak/

Benjamin, R., \& do Rego Wilfrid, L. (2020). Coronavirus: L'Afrique peut profiter de l'aprèscrise pour repenser son industrie. Le Monde Afrique.

https://www.lemonde.fr/afrique/article/2020/05/12/coronavirus-l-afrique-peut-profiter -de-l-apres-crise-pour-relocaliser-son-industrie $6039451 \quad 3212 . \mathrm{html}$

Blore, S. (2020). Gabon: Covid Lockdown Boosts Gold Sales. Artisal Gold Council. https://www.artisanalgold.org/2020/06/gabon-covid-lockdown-boosts-gold-sales/

Bourdillon, Y. (2020). Le Gabon a encaissé le choc Covid-19. Les Echos. https://www.lesechos.fr/monde/afrique-moyen-orient/le-gabon-a-encaisse-le-choc-cov $\underline{\text { id-19-1254704 }}$

Brice, G. (2020). Relance économique: Le gouvernement gabonais met en place sa stratégie post Covid-19. Le Nouveau Gabon.

https://www.lenouveaugabon.com/fr/gestion-publique/0512-16219-relance-economiqu e-le-gouvernement-gabonais-met-en-place-sa-strategie-post-covid-19

Burki, T. (2020). China's Successful Control of COVID-19. https://www.thelancet.com/journals/laninf/article/PIIS1473-3099(20)30800-8/fulltext

Campbell, M. (2020). Will Complement Inhibition Be the New Target in Treating COVID19-Related Systemic Thrombosis? Circulation, 141, 1739-1741.

https://www.ahajournals.org/doi/full/10.1161/CIRCULATIONAHA.120.047419 https://doi.org/10.1161/CIRCULATIONAHA.120.047419

Carpenter, J. W. (2020). The Main Oil Producing Countries in Africa. Investopedia. https://www.investopedia.com/articles/investing/101515/biggest-oil-producers-africa.asp

Dzonteu, D.-C. (2020). Gestion du Covid-19: Les propositions du RPG. Gabon Review. https://www.gabonreview.com/gestion-du-covid-19-les-propositions-du-rpg/

Eyene, M. S. C. (2020a). Au Gabon, la crise du Covid-19 plombe le moral des populations. Le Nouveau Gabon.

https://www.lenouveaugabon.com/fr/sante-social/0411-16047-au-gabon-la-crise-du-co vid-19-plombe-le-moral-des-populations

Eyene, M. S. C. (2020b). Relance de l'économie: Du fait de leur proximité avec les PME, les microfinances pourraient jouer un rôle majeur. Le Nouveau Gabon.

https://www.lenouveaugabon.com/fr/gestion-publique/1211-16095-relance-de-l-econo mie-du-fait-de-leur-proximite-avec-les-pme-les-microfinances-pourraient-jouer-un-ro le-majeur

Eyene, M. S. C. (2020c). Stratégie de relance post-Covid-19: Ces réformes des finances publiques envisagées. Le Nouveau Gabon.

https://www.lenouveaugabon.com/fr/gestion-publique/2210-15984-strategie-de-relanc e-post-covid-19-ces-reformes-des-finances-publiques-envisagees

Galal, S. (2021). Number of Coronavirus (COVID-19) Cases in the African Continent as of April 14, 2021, by Country. 
https://www.statista.com/statistics/1170463/coronavirus-cases-in-africa/

GIGA focus Afrika (2020). L'Afrique après les verrouillages de Covid-19: Impacts et perspectives économiques.

https://www.giga-hamburg.de/en/publications/21606562-africa-after-covid-19-lockdo

wns-economic-impacts-prospects/

Horowitz (2020). The Global Coronavirus Recession Is Beginning. CNN. https:/edition.cnn.com/2020/03/16/economy/global-recession-coronavirus/index.html

Info Covid19 Gabon (2021). Situation epidemiologie au Gabon. https://twitter.com/Covid19GOUVGA/status/1403458258170519553

Jayaram, K., Leke, A., Ooko-Ombaka, A., \& Sun, Y. (2020). Tackling Coronavirus in Africa. https://www.mckinsey.com/featured-insights/middle-east-and-africa/tackling-COVID19-in-africa

Klomegah, K. K. (2020). COVID-19: Urgent Need for African Governments to Upgrade the Health Systems.

https://www.indepthnews.net/index.php/sustainability/health-well-being/3520-covid-1 9-urgent-need-for-african-governments-to-upgrade-the-health-systems

Kraaijenbring, J. (2020). The Bright Side of Covid-19: Seven Opportunities of the Current Pandemic. Forbes.

https://www.forbes.com/sites/jeroenkraaijenbrink/2020/03/23/the-bright-side-of-coron a-seven-opportunities-of-the-current-pandemic/?sh $=774 \mathrm{~d} 5 \mathrm{a} 87785 \mathrm{c}$

Kurtz, J. (2020). Policy Seminar: COVID-19 Impacts on African Agricultural Trade and Food Security. IFRI Blog.

https://www.ifpri.org/blog/policy-seminar-covid-19-impacts-african-agricultural-trade -and-food-security

Mapping of Active Cases in Gabon (2021). https://twitter.com/Covid19GOUVGA/status/1403458258170519553

Mateso, M. (2020). Coronavirus en Afrique: Mobilisation des artisans locaux pour la fabrication des masques de protection. Franceinfo: Afrique.

https://www.francetvinfo.fr/monde/afrique/societe-africaine/coronavirus-en-afrique-m obilisation-des-artisans-locaux-pour-la-fabrication-des-masques-de-protection 39401 $\underline{15 . h t m l}$

McKibbin, W., \& Fernando, R. (2020). The Global Macroeconomic Impacts of COVID19: Seven Scenario. CAMA Working Paper No. 19/2020.

http://www.sensiblepolicy.com/download/2020/2020WorkingPapers/2020 19 CAMA COVID19 mcKibbin fernando 0.pdf https://doi.org/10.2139/ssrn.3547729

Michael, C. (2020). Coronavirus et Afrique-Au Gabon, une réaction rapide et progressive. https://www.institutmontaigne.org/blog/coronavirus-et-afrique-au-gabon-une-reaction -rapide-et-progressive

Mounombou, S. (2020). Covid-19: Le Gabon renforce son dispositif grâce à un prêt de 5 milliards de FCFA. Gabon Review.

https://www.gabonreview.com/covid-19-le-gabon-renforce-son-dispositif-grace-a-unpret-de-5-milliards-de-fcfa/

OECD (2020). COVID-19 and Africa: Socio-Economic Implications and Policy Responses. OECD.

https://www.oecd.org/coronavirus/policy-responses/covid-19-and-africa-socio-econom i\%20c-implications-and-policy-responses-96e1b282/

Olagboye, B. (2020). En Afrique, le Covid-19 révèle la nécessité de faire participer les citoyens à leurs systèmes de santé. Le Monde Afrique. 
https://www.lemonde.fr/afrique/article/2020/05/17/en-afrique-le-covid-19-revele-la-ne cessite-de-faire-participer-les-citoyens-a-leurs-systemes-de-sante 6039948 3212.html

Poatail FinDev (2021). Gabon: Le Covid-19 fait perdre plus de 12000 emplois. https://www.findevgateway.org/fr/actualites/gabon-le-covid-19-fait-perdre-plus-de-12000-emplois

Rachael, R. (2020). Coronavirus Outbreak Officially Declared a Pandemic. WHO Says. Live Science. https://www.livescience.com/coronavirus-pandemic-who.html

Randa, G. Z. (2020). Covid19 Is an Opportunity to Restart Education. Here Are 4 Ways How. World Economic Forum.

https://www.weforum.org/agenda/2020/10/covid-19-education-reset/

Riku, E., \& Alexander, P. (2020). COVID-19 and Beyond: How Can Africa's Health Systems Cope? OEDC.

https://oecd-development-matters.org/2020/04/07/covid-19-and-beyond-how-can-afri cas-health-systems-cope/

Schiex, E., Nze, I. O., \& Niamkey, A. (2020). Au Gabon, l'impact du Covid-19 pèse sur une économie fragile. Focus France 24.

https://www.france24.com/fr/\%C3\%A9missions/focus/20201026-au-gabon-l-impact-d u-covid-19-p\%C3\%A8se-sur-une-\%C3\%A9conomie-fragile

Schneider, P., Pivodic, F., \& Yoo, K.J. (2020). How Much Haelth Financing Does SubSaharan Africa Need to Fight COVID-19 (Coronavirus)?

https://blogs.worldbank.org/health/how-much-health-financing-does-sub-saharan-afri ca-need-fight-covid-19-coronavirus

Stanford University (2020). COVID-19: The Impact in Africa. Stanford King Center on Global Development. https://kingcenter.stanford.edu/events/covid-19-impact-africa

The World Bank (2020). Gabon COVID-19 Strategic Preparedness and Response Project (SPRP) (P173927).

https://documents1.worldbank.org/curated/en/386861588792319126/pdf/Project-Inform ation-Document-GABON-COVID-19-Strategic-Preparedness-and-Response-Project-SP RP-P173927.pdf

The World Bank (2021). Food Security and COVID-19.

https://www.worldbank.org/en/topic/agriculture/brief/food-security-and-covid-19

UN (2020). COVID-19 Cadre de Riposte Socio-économique des Nations Unies au Gabon. https://gabon.un.org/sites/default/files/2020-08/Gabon\%20Cadre\%20de\%20Riposte\%2 OSE\%20COVID19\%20Aout\%202020 0.pdf

UNECE (2021). Harnessing E-Commerce Post-COVID-19: Opportunities and Challenges for Transition Economies.

https://unece.org/trade/events/harnessing-e-commerce-post-covid-19-opportunities-a nd-challenges-transition-economies

Wells, L. (2020). Study Identifies Dire Economic Impact of COVID-19 in Africa. Johns Hopkins University.

https://hub.jhu.edu/2020/10/15/covid-19-has-dire-economic-impact-on-africa/

WHO (2020). Coronavirus Disease 2019 (COVID-19). Situation Report.

https://www.who.int/docs/default-source/coronaviruse/situation-reports/20200423-sitr ep-94-covid-19.pdf?sfvrsn=b8304bf0 2\#: : :text=Retrospective\%20investigations\%20by \%20Chinese\%20authorities, \%2C\%20some\%20did\%20not.

WHO (2021). Weekly Epidemiological Update on COVID-19.

https://www.who.int/publications/m/item/weekly-epidemiological-update-on-covid-19 ---13-april-2021

WORLDOMETER (2021a). Reported Cases and Deaths by Continent. Worldometer Coro- 
navirus Population.

https://www.worldometers.info/coronavirus/?utm campaign=homeAdvegas1

WORLDOMETER (2021b). Reported Cases and Deaths by Country or Territory. Worldometer Coronavirus Population.

https://www.worldometers.info/coronavirus/?utm campaign=homeAdvegas 1 ?\%22\%20 \%5Cl\%20\%22countries\%3Ca\%20href

Wren-Lewis, S. (2020). The Economic Effects of a Pandemic. Social Europe. https://socialeurope.eu/the-economic-effects-of-a-pandemic 